\title{
dossier NEW ENVIRONMENTS, SAME JOBS: \\ the role of professional journalism \\ stimulating debate on elections across social media networks
}

Copyright (C) 2016 SBPjor / Associação Brasileira de Pesquisadores em Jornalismo
FERNANDA CAVASSANA DE CARVALHO

Universidade Federal do Paraná, Brazil

ISABELE BATISTA MITOZO

Universidade Federal do Paraná, Brazil

\begin{abstract}
Taking into account the new configurations of online communication between traditional journalism and its readers, this study analyzes how Internet users reacted to posts on the official Facebook pages of eleven Brazilian newspapers when they published news about the 2014 presidential elections. This analysis will focus on comments on posts that mentioned at least one of the main candidates (Aécio Neves, Dilma Rousseff, and Marina Silva/Eduardo Campos). Two variables were considered: the format of the comments and their justification. A quantitative content analysis methodology was used, and statistical tests pertinent to categorical data were applied. Results showed that the main formats used for comments were criticism and praise of the candidates, also the most common justification was one "of position", especially when the praise format was chosen, which allows us to characterize Brazilian electors as supporters, given the polarization in the campaign.
\end{abstract}

Keywords: Political journalism. Election coverage. Social network sites. 2014 Elections. Public Opinion.

\section{NOVOS AMBIENTES, MESMAS FUNÇÕES: o jornalismo profissional fomentando o debate sobre eleições nas redes sociais digitais}

RESUMO - Tendo em vista as novas configurações da comunicação do jornalismo convencional com seus leitores em ambiente online, este trabalho objetiva analisar como o internauta se manifestou nas páginas oficiais de onze jornais brasileiros na rede Facebook, quando da publicação de notícias referentes às eleições presidenciais de 2014. A unidade de análise são os comentários feitos aos posts que citavam ao menos um dos principais candidatos (Aécio Neves, Dilma Rousseff, Marina Silva/Eduardo Campos). Observam-se duas variáveis: formato do comentário e justificativa utilizada. A metodologia é a análise de conteúdo quantitativa, com aplicação de testes estatísticos adequados para dados categóricos. Dentre os resultados, verificou-se que os formatos predominantes nos comentários foram crítica e elogio direcionados aos candidatos, a justificativa de maior ocorrência foi aquela "de posição", ainda mais presente quando o formato foi elogio a candidato(a), o que permite caracterizar o eleitor brasileiro em 2014 como torcedor, considerando a polarização da campanha.

Palavras-chave: Jornalismo político. Cobertura eleitoral. Redes sociais digitais. Eleições 2014. Opinião Pública. 

profesional promoviendo el debate sobre las elecciones en las redes sociales

RESUMEN - Teniendo en cuenta las nuevas configuraciones de la comunicación del periodismo convencional con sus lectores en la red, este artículo analiza cómo los usuarios de internet hicieron comentarios en las páginas oficiales de once periódicos brasileños en Facebook, en las noticias sobre las elecciones presidenciales de 2014. La unidad de análisis son los comentarios a los posts que citaban por lo menos uno de los tres candidatos principales (Aécio Neves, Dilma Rousseff, Marina Silva / Eduardo Campos). La metodología es cuantitativa de análisis de contenido, con la aplicación de pruebas estadísticas adecuadas a datos categóricos para analizar dos variables: formato del comentario y justificación utilizada. En los resultados, se observa que los formatos predominantes en los comentarios eran críticas y elogios dirigidos a los candidatos. La justificación más frecuente fue la "de posición”, más presente cuando el formato fue "elogio al candidato". Esto caracteriza el elector brasileño como un aficionado por sus candidatos, teniendo en cuenta la polarización de la campaña en 2014.

Palabras clave: Periodismo político. Cobertura electoral. Redes sociales. Elecciones 2014 en Brasil. Opinión Pública.

\section{Introduction}

Traditional journalism has opened spaces for new possibilities of interaction. This has been a constant demand of the contemporary public since the invention of digital social media, which provides a new space for direct communication between readers and the newspaper, and also among the public itself: the comments. Because newspapers have to some extent lost control of what readers publish and comment about the newspapers' content, it can be said that the comments sections foster a computer-mediated human interaction, even though the writing of the news has not essentially changed (playing the role of a gatekeeping' process), because it allows for long discussions between two or more people (STROMER-GALLEY, 2000, p.117).

In mid-2014 in Brazil, more than just using their social media profiles ${ }^{2}$ to leave a "Good morning" message to their readers, newspapers noticed that a certain kind of hard news had gained great interest in the public's eye: the 2014 presidential election. The presidential election was characterized by the death of one of the candidates, by tense debates, corruption scandals and a strong polarization between the two biggest parties in the country - Labours Party (PT) and Brazilian Social Democracy Party (PSDB) - (and a 
campaign that presented itself as an alternative - Brazilian Socialist Party - PSB/ Sustainability Party - REDE coalition): all this contributed to make Internet users interact and voice their opinions, mainly on the social media profiles of newspapers and candidates.

By observing this context, this study aims at analyzing how Internet users expressed themselves during that time on the Facebook profile of eleven Brazilian newspapers: Folha de S. Paulo, O Estado de S. Paulo, and O Globo - which are national newspapers -, A Tarde (BA), Correio Braziliense (DF), Correio do Estado (MS), Diário do Pará (PA), Gazeta do Povo (PR), O Estado de Minas (MG), O Povo (CE), and Zero Hora (RS). The analysis will focus on comments that addressed either the newspaper itself or other commentators, and which were made on posts that mentioned at least one of the main presidential candidates Aécio Neves, Dilma Rousseff, Marina Silva (who had been represented before by mentions to Eduardo Campos, the deceased candidate that Marina substituted). Two variables were considered in each comment: format (criticism or praise) and the type of justification (of position, internal or external).

This study starts with a theoretical section to present the new relationships between journalism, social media use, and public opinion. Later, the political landscape that provoked public debate during the 2014 election in Brazil will be contextualized. Later on, the methodology used in the analysis will be presented.

\section{Journalism and the promotion of debate on social media}

Journalism is an institution whose function and rules are socially instituted. Even though it is not always the case, Brazilian journalism is based on impartiality and a pursuit of public interest, which reflects an objective and commercial model of the media a model influenced by the North American standard, in which informative news originated from a social demand for knowledge of everyday facts and events (PARK, 2008). As strong and thorough the North American influence may be, the informative model has never been totally adopted in Brazil (ALBUQUERQUE, 2004). Society is an organism, and journalism, being a part of it, is conditioned by components of society, such as its institutions, its culture and history, as well as the influence of the county's citizens and their consumer behavior. 
Nowadays, producing and publishing informative content is no longer an exclusive attribution of the media. There are countless supplementary ways of obtaining knowledge. The control media used to have over access to information has been deeply altered because the public depends on journalistic information to a lesser degree and has stronger control over the selection of information. Online environments currently display simultaneous gatekeeping and gatewatching 3 processes regarding information publishing and consumption (BRUNS, 2006).

Weber and Coelho (2011) state that "both as an institution and an organization, journalism is a phenomenon of modernity which is continually being transformed". If this transformation is caused by new journalistic approaches that continually are created and adopted to attract and maintain readers, the emergence of the web, especially in its 2.0 format (GOMES et al., 2009), has been the main factor in this process. Nevertheless, this new model has not made the print format entirely obsolete, because the public does not necessarily change their medium of choice. What happens, in fact is that "when new production, transmission, and storage forms are integrated to social life, the current forms of media reception and consumption aren't immediately banned, their outline and parameters are, nonetheless, rearranged" (KNEWITZ; JACKS, 2011 , p.205).

This means that, when media outlets migrated to websites and social media, they had to make changes on their production and publishing platforms and specificities, while maintaining their institutional commitment to producing information and promoting public debate. Because of this, the digital environment has reshaped an essential element of the relationship between journalism and its readers: the reading contract. This happens because, given the opportunity to interact, especially through comments, the public will be exposed to a myriad of interpretations that expand and outnumber the ones provided by the journalistic text: those of other readers own framing of the information, on the newspapers' websites and social media profiles. What occurs, then, when journalism enters digital social media is what could be called "conversational interactivity [...], which allows the user to interact with journalists and other users" (THURMAN, 2015, p.358). All this means that a new dynamic of journalistic production is created by the fact that there are other receptors between the producer of the information and the receptor, who is generally singular in number. 
In this context, comments made by readers are disruptive of "the traditional publishing model, as it sought to present news and comment on current events from the point of view of the audience" (THURMAN, 2015, p.362), even though this author acknowledges the role of moderation and, consequently, the relative character of the ease of interaction. This serves as an example of the social response system proposed by Braga (2006), which is characterized by a circulation of messages initially produced by the media and then altered by the public after it is received. This interaction occurs through socially appropriate devices, and is exemplified in comments made by readers in journalistic posts.

There have been a number of researches attempting to grasp the importance of this new practice, both in politicalinstitutional platforms (SAMPAIO et al., 2010), and about comments on the websites and social media profiles of various media outlets (BARROS; CARREIRO, 2015; ROSSETO et al., 2015; CERVI, 2013). These researches have sought to analyze the public debate through deliberative criteria, always considering that the Internet may be an extension of the public sphere (DAHLBERG, 2002), as was originally proposed by Habermas (2003), and direct interaction occurs not only between Internet users and media outlets but also among Internet users themselves.

The second group of researches mentioned above is more closely related to the analysis conducted in this study. In that group, it can be noted that the work of Barros and Carreiro (2015) focuses on debates on comments sections of journalistic posts, emphasizing variables such as "topic", "reciprocity", "justification", and "degree of justification". Their research concludes that when discussion is about topics that are distant from everyday life and more closely related to the political elites (such as the "Mensalão" case and the racial and income-related quotas law) monologic comments predominate. The same happens in relation to justification and their higher degree of elaboration. Cervi (2013) studied comments about the 2010 presidential election on the O Estado de São Paulo website and notes that users tend to use that space mainly to discuss among each other, but that justification also becomes rarer as the date of the election drew closer. Rosseto et al. (2015) analyzed Facebook posts made by users regarding the water crisis in São Paulo, and focused on reflexivity, especially as the debate progressed. The authors conclude 
that users were more interested in presenting information on their timelines and less inclined to provide personal comments on what they were sharing.

These studies demonstrate that, regardless of the intensity of interaction and discussion that may be reached, people seek to be informed, to share that information, to comment and to discuss, and mainly to generate debate. It is this specific action of generating debate that originates public opinion. Journalism, in its goals of informing and guiding the public (PARK, 2008), has a direct bearing on the construction of reality, especially when presenting facts that are more distant from the readers' immediate personal experiences. To use different outlets and social media in order to be informed about the elections is a way of accessing different views on the election in the same environment.

In 2014, the coverage of the presidential election in Brazil saw a media convergence of interfaces and outlets. It could be noted that the media, which participated on the Internet via their websites and digital social media profiles, followed the debates on television in real time. By doing this, the media influenced and directed the debate among citizens who followed that information and commented on spaces the outlets reserved for them on their websites (MITOZO; MASSUCHIN; CARVALHO, 2015). This allowed for the creation of a digital communicational arena where political discussion reached great proportions, even though discussion limited itself to agendas and events of the campaign and there was no thematic deepening concerning popular demands or the candidates' proposals. Not only did the news frame the presidential election as a "horse race" (PORTO, 2004), but so did also the commentators as they assumed a role of supporters in the election (BRUGNAGO; CHAIA, 2014). This gave the comments a personal trait.

Even in social spaces of the web more related to having fun, such as Facebook, great political interest from Internet users could be observed, and discussion was widespread, especially where journalistic posts were concerned. The database used by this analysis is comprised of over 600,000 comments. To allow for a clear understanding of the causes of citizens' broad engagement on the facts of the campaign, the next section will briefly present a context of the period studied. 


\section{Context of the 2014 presidential election}

In order to outline the political context of the campaign, this section will present the main facts that impacted the design of the political scene in Brazil between July and October 2014. One of the differences between that election and the ones that took place before was the Brazilians' heavy use of digital social media. Along with the journalistic coverage of the elections, the online environment saw a significant rise of interest in the topic. The debate, later polarized, followed a campaign that culminated in a runoff voting between two parties that had been rivals since 1994: Labours Party (PT) - which had been in power for the three previous terms - and Brazilian Social Democracy Party (PSDB).

In 2014, Dilma Rousseff's government - politically frail due to accusations of corruption in Petrobras, and to the economic crisis caused by new policies - saw great opposition from big and small, left-wing and right-wing parties. The original campaign had eleven presidential candidates, three of which represented a party coalition (TSE, 2015).

The pro-government coalition, which was called "Alliance with Peoples' Strength", composed by PT (the party of the incumbent Dilma Rousseff) and eight other parties among them the Brazilian Democratic Movement Party (PMDB), the vice-president (Michel Temer) party. This candidacy represented a continuity of national policies implemented by PT in its previous ten years in power, since the election of Luís Inácio Lula a Silva in 2002. In the federal government, besides her first term as president, between 2010 and 2014, Dilma had held positions in the Mines and Energy Ministry and Chief of Staff of President Lula during his two terms as president.

The main opposition candidacy was a coalition calling itself "Brazil for Change", which was composed by PSDB and other eight parties, and had Aécio Neves as candidate for president and Aloysio Nunes as candidate for vice-president, both from PSDB. Currently a senator, Aécio Neves had already held a position in the Executive branch for four years (2003-2006) as governor of the state of Minas Gerais.

There was also a "United for Brazil" coalition composed by the Brazilian Socialist Party (PSB), and five other parties. The exgovernor of the state of Pernambuco, Eduardo Campos (PSB), was the candidate and Marina Silva, who was also affiliated with PSB, run for vice-president. Marina had not been able to register her candidacy for 
president, like she had done in 2010, because her newly-created party - Sustainability Network (REDE) - had had its registration denied by the Superior Electoral Court in October 2013, the latest date for candidates to affiliate to a party to run in the 2014 elections (TSE, 2013).

The eight remaining candidacies represented only their own party: Luciana Genro (Socialism and Liberty Party - PSOL); Pastor Everaldo (Social Christian Party - PSC); Eduardo Jorge (Green Party - PV); Zé Maria (United Socialist Labours' Party - PSTU); José Maria Eymael (Christian-Social Democratic Party - PSDC); Levy Fidélix (Brazilian Labour Renewal Party - PRTB); Mauro Iasi (Brazilian Communist Party - PCB); and Rui Costa Pimenta (Labours' Rights Party - PCO). Not only were they individual parties, but also considered "tiny", due to their own limited representation in the political field. Those parties had very few representatives in Congress, and therefore very little exposure in the media, and very little free-to-air time on TV and radio, or in the debates on television. All of those individual candidacies presented themselves throughout the campaign as opposition.

Marina Silva had received almost 20 million votes in the 2010 elections. In spite of her being candidate for vice-president to Eduardo Campos in 2014, his campaign was initially seen as less competitive, because he was not very well known nationally. Marina Silva took over the candidacy for president, with Beto Albuquerque (PSB) as her vicepresident, after a helicopter accident killed Campos in August 13th, 2014. This change brought about important alterations to the arena of candidates: Marina represented a third force in the campaign; she affirmed that she was capable of curbing the polarization between the candidates of PT and PSDB.

The PSB candidate even tied with Dilma Rousseff in electoral polls for the first round. Marina also led polls for the second round, in scenarios both against Dilma Rousseff and Aécio Neves, who as the polls showed she even beat in the first round. Before the election, Marina was seeking political alliances that would give her more votes. This caused her to relinquish a number of policies in her original government plan, which raised harsh criticism from her opponents. Voters also gave poor ratings to her performance in debates, which led to her being defeated by the candidate of PSDB, whose campaign had not very impressive until then.

The first round of the election took place in October 5 th. Dilma Rousseff amassed $43.267,668$ votes (41.59\% of the valid votes) and Aécio Neves received $34,897,211$ (33.55\% of the valid votes). These 
results took both candidates to the second round, which deepened the polarization of the presidential campaign between PT and PSDB, as has been the case since 1994 (CERVI, 2014b).

In the second round, the main support for Aécio Neves came from the candidate who had come third in the first round, Marina Silva, who had garnered $22,176,619$ votes $(21.32 \%$ of the valid votes). Along with PSB, Marina, while asking for a few changes in his government plan, formally supported the opposition candidate. In the second round, Aécio was also supported by candidates Eduardo Jorge (PV); Pastor Everaldo (PSC); José Maria Eymael (PSDC); Levy Fidélix (PRTB), along with their respective parties.

Even when not supporting PSDB in the second round, none of the remaining candidates formally declared support to Dilma Rousseff, which confirmed the oppositional stance adopted by leftwing parties. Luciana Genro (PSOL) took the position of "no vote for Aécio", while Zé Maria (PSTU), Rui Costa Pimenta (PCO), and Mauro lasi (PCB) proposed to cast an invalid vote. This meant that, while Aécio Neves was formally supported by many parties in the second round, Dilma Rousseff retained the same alliances the composed her original coalition, and was formally supported by few political actors acting independently of their parties.

According to some authors, the atmosphere of the 2014 election reflected a resurgence of Brazilians' identification with a political left or a political right. This has been seen as consequence of the demonstrations that took place in June 2013 (BRUGNAGO; CHAIA, 2014). According to Brugnago and Chaia (2014), the behavior displayed by supporters of PT and PSDB showed tensions that were similar to the confrontations between supporters of rival soccer teams during classic matches. That behavior also pointed to a return of politics as a main topic of everyday discussion in Brazil.

While the faction that called itself left-wing mobilized against a supposed neoliberal project defended by PSDB, the conservative right developed its ideology around a strong Anti-PT sentiment in that they claimed to be independent of any political party. The discussions held by the latter group were a radicalization of values considered to be right-wing (BRUGNAGO; CHAIA, 2014, p.102). Facebook was, in this context, one of the main online stages for this polarization.

Even with part of the public having mobilized, with open support from the third most voted candidate and other candidates to Aécio, the opposition was not able to defeat the government in the 
election. The second round voting took place in October 26th, and Dilma Rousseff was re-elected by $54,501,118$ votes (51.64\%) against $51,041,155$ votes for Aécio Neves (48.36\%). The small, 3\% difference between valid votes for each candidate made the 2014 presidential election the most disputed in the history of Brazilian democracy.

Alongside with what happened on the political stage, voters took to intense and passionate discussions, either attacking or defending each side. Especially Facebook, with its 59 million users in Brazil (BRUGNAGO; CHAIA, 2014), became one of the main arenas for debate. It should be noted that the newspapers profiles on Facebook were one of the greatest promoters of debate, especially because readers still hold those outlets in high regard.

The next section will present the methodology for analysis used in this study to describe how the debate unfolded on the Facebook pages of eleven Brazilian newspapers.

\section{Methodological strategies}

This research aims to analyse how Internet users expressed themselves through comments in the 2014 presidential campaign on the Facebook pages of Brazilian newspapers. The analysis takes into consideration the fact that those newspapers publish hard news (CERVI, 2013) even in an environment such as social media because it acknowledges the possibility of readers using other sources to access information about the campaign; sources such as alternative outlets, blogs, and candidates themselves. This goes to show that journalism as an institution still has an important role in the debate. It is important to state that this study goes beyond a mere analysis of the diffusion process, in that it analyses responses to published content, focusing on comments posted by readers on social media. This delimitation is based on considerations made by Braga (2006), who says that the process of media communication does not end in the cycle between production and reception. Nevertheless, it encompasses responses, i.e. interaction of the reading public with posts and with other readers, based on the published content already produced and received, through comments, and "likes" and shares in the case of Facebook. This means that prior news distribution is seen as a process that precedes these exchanges and, as a consequence, is not considered within the scope of this analysis. 
The following questions guide the research: 1) Did Internet readers interact with content produced by media organizations during the 2014 elections, thus making journalism a promoter of public debate on social media? 2) Which format did these comments take? 3) Were Facebook users concerned with justifying their opinions when interacting with journalistic posts?

Eleven newspapers analyzed in this research as presented in chart 1 below. Of these, Folha de S. Paulo, O Estado de S. Paulo, and O Globo have national coverage. The other eight newspapers cover news in their own localities. Because of this, newspapers from the five regions of Brazil were chosen; this was done to outline a wide panorama of the discussion promoted by journalism.

Chart 1 - Analysis of the fan pages in Brazilian newspapers

\begin{tabular}{|l|c|l|}
\hline \multicolumn{1}{|c|}{ Newspaper } & City-State & \multicolumn{1}{c|}{ Website Address (URL) } \\
\hline A Tarde & Salvador - BA & facebook.com/atarde.online \\
\hline $\begin{array}{l}\text { Correio } \\
\text { Braziliense }\end{array}$ & Brasília - DF & $\begin{array}{l}\text { facebook.com/ } \\
\text { correiobraziliense }\end{array}$ \\
\hline $\begin{array}{l}\text { Correio do } \\
\text { Estado }\end{array}$ & Campo Grande - MS & $\begin{array}{l}\text { facebook.com/ } \\
\text { correiodoestado }\end{array}$ \\
\hline Diário do Pará & Belém - PA & facebook.com/DOLdiarioonline \\
\hline Estado de Minas & Belo Horizonte - MG & facebook.com/EstadodeMinas \\
\hline Folha de S. Paulo & São Paulo-SP & facebook.com/folhadesp \\
\hline Gazeta do Povo & Curitiba - PR & facebook.com/gazetadopovo \\
\hline $\begin{array}{l}\text { O Estado de S. } \\
\text { Paulo }\end{array}$ & São Paulo - SP & facebook.com/estadão \\
\hline O Globo & Rio de Janeiro - RJ & facebook.com/jornaloglobo \\
\hline O Povo & Fortaleza - CE & facebook.com/OPOVOOnline \\
\hline Zero Hora & flegre - RS & facebook.com/zerohora \\
\hline
\end{tabular}

Source: Facebook

Netvizz application was used to extract all the content published on fan pages of the aforementioned publications during 
the period of the presidential campaign, from July 1 st to October 26th, 2014. Posts on the fan pages and their comments made by the public were considered. From this, reading and categorization of the obtained data were conducted using Content Analysis, and its methodological strategies made it possible to measure certain attributes present in the text (BAUER, 2013) based on a previously written codebook ${ }^{4}$.

Following the line of investigation employed by Cervi (2013), Barros and Carreiro (2015), and Rosseto et al. (2015), this analysis used deliberative criteria. First, the main topic of each post was classified. This was done because newspapers publish different content, not only coverage of the election. In this case, only posts about the presidential election were considered, i.e. those that mentioned any of the three main candidates by name. That is to say that the analysis focused of posts that textually contained the names of Dilma, Aécio, and/or Marina - as well as Campos before his death and being replaced by another candidate.

Subsequently, the content of comments to those specific posts, i.e. comments that also mention the candidates, was analyzed. The goal was to measure specific characteristics of the content posted by readers regarding the original journalistic content. The analysis took into consideration the fact that this was a favorable environment for political debate. The comments were categorized in relation to two variables: "format" - which identified whether the comment was one of criticism or praise (of the topic, the newspaper itself or of other users) - and "justification" - which observed the reasons why that specific user commented on the post and also the characteristics of their opinion.

Regarding the format, it is important to say that some comments expressed neither criticism nor praise, which was considered an "indeterminate format". Examples of this format could be found in comments that simply mentioned the name of a candidate. With regard to justification, even when a comment did not present a justification in itself, but exposed all the same the political leanings of the commentator, this comment was considered one "of position" (JENSEN, 2003; SAMPAIO et al., 2010; CERVI, 2013). The "internal" category was attributed to personal justification presented by the commentator as life experience, derived from personal stories. The "external" category was attributed to comments that referenced external sources and based their content on data and examples 
(JENSEN, 2003). When the author provided neither justification nor their political leanings, their comment was considered as "no justification" (N/J).

By using categorical and qualitative variables, the analytical method consisted of descriptive statistics at first, so the data could be displayed. Subsequently, contingency tables were used to crossreference the variables, and statistical tests appropriate to categorical data were conducted to establish the correlation between them. To obtain this correlation, chi-square was calculated; this is a coefficient that is able to measure statistical differences in compared distributions, also relations of dependence between variables, and standardized residual, which locates in which pair of categories those differences are concentrated. These residuals can be significant if their value is outside a -1.96 and +1.96 range, indicating an absence value or a concentration value of the analyzed characteristic that surpasses the expected value for a relation of independence (CERVI, 2014a).

Finally, a correspondence analysis was applied. A twodimensional graph was obtained in which the relations between the variable categories that were cross-reference could be visualized. At this point these relations had already been highlighted by the standardized residuals. For this analysis, each point in the Cartesian plane represents a category of the format and justification variables. The distance or proximity between points represents, respectively, a higher or lower correspondence between the characteristics represented by each point. It is, therefore, a visual strategy to summarize the statistical relations that have been measured. Statistically, in correspondence analysis, the inertia value for each graphic dimension indicates the explanation percentage of that axis (dimension 1 horizontal and dimension 2 vertical) in the model.

\section{The debate generated on Facebook by newspaper election coverage}

It is necessary, with regard to the empirical corpus, to present a brief overview of the public debate originated from newspapers' posts on Facebook, i.e. the volume of posts and comments during all the period for each separate newspaper. For this, table 1 presents the overall volume of posts, which mention the presidential campaign and comments regarding said campaign, over the period of the election (from 07/01 to 10/26/2014). 


\begin{tabular}{l|c|c|c|c}
\hline \multicolumn{1}{l}{ Table 1 - Posts and comments per newspaper } \\
\hline Newspaper & $\begin{array}{c}\text { General } \\
\text { Posts }\end{array}$ & $\begin{array}{c}\text { Campaign } \\
\text { Posts }\end{array}$ & $\begin{array}{c}\text { Comments } \\
\text { on campaign } \\
\text { posts }\end{array}$ & $\begin{array}{c}\text { Average } \\
\text { Comment/ } \\
\text { post }\end{array}$ \\
\hline A Tarde & 1319 & $269(20.4 \%)$ & 1902 & 7.1 \\
\hline Correio Braziliense & 2207 & $191(8.65 \%)$ & 3342 & 17.5 \\
\hline Correio do Estado & 1383 & $54(4 \%)$ & 711 & 13.2 \\
\hline Diário do Pará & 2778 & $41(1.5 \%)$ & 377 & 9.2 \\
\hline Folha de S. Paulo & 5675 & $882(15.5 \%)$ & 417428 & 473.3 \\
\hline Gazeta do Povo & 2891 & $223(7.7 \%)$ & 1321 & 5.9 \\
\hline O Estado de Minas & 1899 & $80(4.2 \%)$ & 79 & 1.0 \\
\hline O Estado de S. Paulo & 5091 & $431(8.5 \%)$ & 112137 & 260.2 \\
\hline O Globo & 4028 & $154(3.8 \%)$ & 81095 & 526.6 \\
\hline O Povo & 2691 & $138(5.1 \%)$ & 7651 & 55.4 \\
\hline Zero Hora & 4189 & $111(2.65 \%)$ & 2009 & 18.1 \\
\hline Total & 34151 & 2574 & 628052 & 244 \\
\hline \hline Source: Research & $649 \%$ & Polical Com & \\
\hline
\end{tabular}

Source: Research Group for Political Communication and Public Opinion (CPOP/UFPR)

Firstly, it can be seen that the newspapers which posted the most content about the election were A Tarde $(20.4 \%$ of all their posts) and Folha de S. Paulo (15.5\%). It is also significant that Gazeta do Povo and Correio Braziliense, regional newspapers, dedicated approximately $8 \%$ of their posts to the national campaign, which was almost the same percentage for O Estado de S. Paulo (8.5\%), a national newspaper, and surpassed the national daily, O Globo (3.8\%). It is important to know that the presidential campaign happens at the same time as the state elections in Brazil. As consequence, the state elections compete with the presidential election for coverage time in media outlets.

However, in absolute numbers of posts and comments, national newspapers had the greatest importance. Each of the national newspapers had many times more comments than all the regional newspapers combined. Folha de S. Paulo, O Estado de S. Paulo, and O Globo concentrated 610,660 comments, $97 \%$ of the analyzed total $(628,052)$. This superiority of national newspapers can also be seen on the average of comments per post about the election, which confirms 
the observation that their posts concentrated the political debate amongst users. In comparison, an important average was the one displayed by $\mathrm{O}$ Globo, where 526 comments mentioned candidates in posts, which the newspaper also mentioned as candidates. In spite of $\mathrm{O}$ Globo having published less about the election than Folha de $\mathrm{S}$. Paulo and $\mathrm{O}$ Estado de S. Paulo, the debate about the posts published by that newspapers occurred anyway, and was comparatively more intense than in the other fan pages analyzed.

The first characteristic analyzed in the comments was the format. According to the classification detailed in the methodology section, the format of the comments was divided in three categories: comments in praise, comments in criticism, and comment that presented neither of those formats. More specifically, the addressees of the comments were analyzed; they could be: candidates, the author of the post, the newspapers, and other Internet users. Table 2 below presents each case in decreasing order.

\begin{tabular}{|c|c|c|}
\hline & Frequency & Percentual \\
\hline Praise of candidate & 266785 & $42.5 \%$ \\
\hline Critics to candidate & 221505 & $35.3 \%$ \\
\hline Undefined Format & 85831 & $13.65 \%$ \\
\hline Critics to government & 15650 & $2.5 \%$ \\
\hline Critics to newspaper & 15167 & $2.4 \%$ \\
\hline Critics to users & 13286 & $2 \%$ \\
\hline Critics to author & 5596 & $0.9 \%$ \\
\hline Praise of government & 3178 & $0.5 \%$ \\
\hline Praise of author & 603 & $0.1 \%$ \\
\hline Praise of users & 298 & $0.05 \%$ \\
\hline Praise of newspaper & 153 & $0.02 \%$ \\
\hline Total & 628052 & $100 \%$ \\
\hline
\end{tabular}

Source: CPOP/UFPR

It should be noted that the main formats were praise $(42.5 \%$ of the comments) and critics (35.3\%) to candidates, who were clearly the focus of the user debate. On the other hand, the newspapers 
themselves received the least amount of praise (0.02\%), and suffered more criticism from the public (2.4\%). It is a surprising fact that commentators did not direct much criticism to the government (2.5\%), even with its leader being candidate to re-election. Internet users did not criticize or praise other users either; those categories received on $2 \%$ and $0.05 \%$, respectively, of the classifications. It is still important to note the deepening of tension between groups of users that were politically opposed, as has been shown by previous studies (BRUGNAGO; CHAIA, 2014).

In the descriptive section of this analysis, the second variable to be discussed is the justification presented in each comment: of the position taken, with internal justification, external justification, or none. It has been assumed that, given journalism's social role, that the analyzed posts contributed to the debate regarding the election. It is thus interesting to check the level of external data used to support and justify users' opinions.

\begin{tabular}{|l|c|c|}
\hline \multicolumn{2}{|l|}{ Table 3 - Commentators' Justification } \\
\hline & Frequency & Percentual \\
\hline Position & 482774 & $76.9 \%$ \\
\hline No justification & 77135 & $12.3 \%$ \\
\hline Internal justification & 53430 & $8.5 \%$ \\
\hline External justification & 14713 & $2.3 \%$ \\
\hline Total & 628052 & $100 \%$ \\
\hline
\end{tabular}

Source: CPOP/UFPR

Table 3 shows that commentators presented their political positions mainly as self-justifiable. They did not seek to give neither internal nor external reasons to support their position. The second most recurrent category was "no justification" (12.3\%), which further shows that users did not state any reasons for their comments about the presidential election, regardless of the format of their comment.

Nonetheless, by cross-referencing the aforementioned variables, it can be seen that, given a significant chi-square coefficient (328471.489), there is a relation of dependence between said variables. The standardized residuals test ( $R p)$, presented on table 4 , shows significant relations between certain categories of the two variables. 
Table 4 - Comments' format by commentators' justification

\begin{tabular}{|c|c|c|c|c|c|c|}
\hline \multirow{2}{*}{ Format } & \multicolumn{5}{|c|}{ Commentators' justification } & \multirow{2}{*}{ Total } \\
\hline & & Position & Internal & External & $\mathrm{N} / \mathrm{J}$ & \\
\hline \multirow{3}{*}{ Praise of author } & Freq. & 315 & 129 & 32 & 127 & 603 \\
\hline & Porc. & $52.2 \%$ & $21.4 \%$ & $5.3 \%$ & $21.1 \%$ & $100 \%$ \\
\hline & Rp. & -6.9 & 10.8 & 4.8 & 6.2 & \\
\hline \multirow{3}{*}{ Praise of candidate } & Freq. & 240895 & 16077 & 3919 & 5894 & 266785 \\
\hline & Porc. & $90.3 \%$ & $6,0 \%$ & $1.5 \%$ & $2.2 \%$ & $100 \%$ \\
\hline & Rp. & 79.1 & -43.9 & -29.5 & -148.5 & \\
\hline \multirow{3}{*}{$\begin{array}{l}\text { Praise of } \\
\text { government }\end{array}$} & Freq. & 2263 & 633 & 261 & 21 & 3178 \\
\hline & Porc. & $71.2 \%$ & $19.9 \%$ & $8.2 \%$ & $0.7 \%$ & $100 \%$ \\
\hline & Rp. & -3.6 & 22.1 & 21.6 & -18.7 & \\
\hline \multirow{3}{*}{ Praise of users } & Freq. & 248 & 29 & 5 & 16 & 298 \\
\hline & Porc. & $83.2 \%$ & $9.7 \%$ & $1.7 \%$ & $5.4 \%$ & $100 \%$ \\
\hline & Rp. & 1.3 & 0.7 & -0.7 & -3.4 & \\
\hline \multirow{3}{*}{ Praise of newspaper } & Freq. & 110 & 30 & 8 & 5 & 153 \\
\hline & Porc. & $71.9 \%$ & $19.6 \%$ & $5.2 \%$ & $3.3 \%$ & $100 \%$ \\
\hline & Rp. & -0.7 & 4.7 & 2.3 & -3.2 & \\
\hline \multirow{3}{*}{ Critics to author } & Freq. & 3620 & 1484 & 195 & 297 & 5596 \\
\hline & Porc. & $64.7 \%$ & $26.5 \%$ & $3.5 \%$ & $5.3 \%$ & $100 \%$ \\
\hline & Rp. & -10.4 & 46.2 & 5.6 & -14.9 & \\
\hline \multirow{3}{*}{ Critics to candidate } & Freq. & 181762 & 24422 & 6133 & 9188 & 221505 \\
\hline & Porc. & $82.1 \%$ & $11.0 \%$ & $2.8 \%$ & $4.1 \%$ & $100 \%$ \\
\hline & Rp. & 27.9 & 40.6 & 13.1 & -109.2 & \\
\hline \multirow{3}{*}{$\begin{array}{l}\text { Critics to } \\
\text { government }\end{array}$} & Freq. & 11023 & 3261 & 846 & 520 & 15650 \\
\hline & Porc. & $70.4 \%$ & $20.8 \%$ & $5.4 \%$ & $3.3 \%$ & $100 \%$ \\
\hline & Rp. & -9.2 & 52.9 & 25 & -32 & \\
\hline \multirow{3}{*}{ Critics to users } & Freq. & 11409 & 1405 & 190 & 282 & 13286 \\
\hline & Porc. & $85.9 \%$ & $10.6 \%$ & $1.4 \%$ & $2.1 \%$ & $100 \%$ \\
\hline & Rp. & 11.8 & 8.2 & -6.9 & -33.4 & \\
\hline \multirow{3}{*}{ Critics to newspaper } & Freq. & 11136 & 2867 & 691 & 473 & 15167 \\
\hline & Porc. & $73.4 \%$ & $18.9 \%$ & $4.6 \%$ & $3,1 \%$ & $100 \%$ \\
\hline & Rp. & -4.8 & 43.9 & 17.8 & -32.2 & \\
\hline \multirow{3}{*}{ Undefined Format } & Freq. & 19993 & 3093 & 2433 & 60312 & 85831 \\
\hline & Porc. & $23.3 \%$ & $3.6 \%$ & $2.8 \%$ & $70.3 \%$ & $100 \%$ \\
\hline & Rp. & -179.0 & -49.3 & 9.4 & 484.8 & \\
\hline \multirow{2}{*}{ Total } & Freq. & 482774 & 53430 & 14713 & 77135 & 628052 \\
\hline & Porc. & $76.9 \%$ & $8.5 \%$ & $2.3 \%$ & $12.3 \%$ & $100 \%$ \\
\hline \multicolumn{7}{|c|}{ Chi-square: $328.471,489$ (Sig: 0,000) } \\
\hline
\end{tabular}

Source: CPOP/UFPR 
By analyzing the table above, it can be seen that, when all types of format and justification are compared, there is a higher than expected concentration on the "position" comment that praises one of the candidates ( $R p$ 79.1). Even if self-positioning was the justification in $82.1 \%$ of the comments criticizing a candidate, this relationship occurs to a lesser degree ( $R p$ 27.9), and there is also a better distribution among possible justifications, especially internal (Rp 40.6), but also external (Rp 13.1).

There was also a comparatively higher than expected concentration of external justifications when commentators criticized (Rp 25) or praised the current government (Rp 21.6), which shows that in this case users were concerned with supporting their opinion with information, data and pertinent facts. It is significant, nevertheless, the presence of high standardized residuals for internal justification in the comments about government, mainly to criticize it ( $R p 52.9$ ), but also to praise it ( $\operatorname{Rp} 25)$.

This goes to show that personal experience was used to support commentators' opinions regarding not only candidates and the government, but also the website itself ( $R p$ 43.9), the author of the post ( $R p$ 46.2), and other users ( $R p .2)$. To illustrate these considerations, graph 1 below presents the results of a correspondence analysis between the two variables.

First, it is important to note that the horizontal distance between points is the most significant, because of the $49.9 \%$ inertia present in dimension 1 , which means that the geometrical distance between each pair of categories is more significant there. After identifying the justification categories, four groups can be seen. The fact that comments without format or justification are isolated suggests that a commentator who intends to express praise or criticism in the course of the debate needs to have a justification for doing so. On the other hand, commentators who praise or criticize candidates or other users tend to use only their own political leanings to support their comments, as we can see on the graph below. 
Graph 1 - Correspondence between format and justification

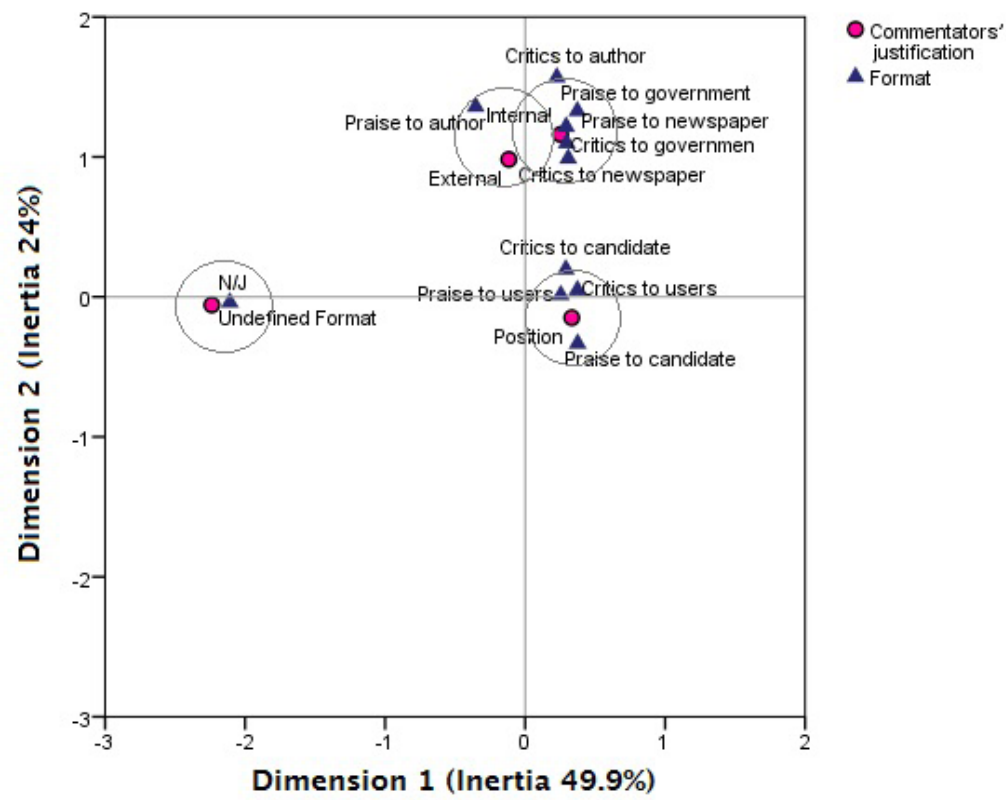

Source: CPOP/UFPR

This graph presents another important factor; that even though external justification is provided to a degree that is higher than expected if there were interdependence, for praise and criticism of government and the website itself, as shown in table 4; distributed, those comments are more frequently justified by personal and life experience, which is proven by the agglomeration in the graph. On the other hand external justification tends to support praise of the author although the standardized residual is not the highest on the line in Table 4.

\section{Conclusions}

The new configuration of journalism, as an element of promotion of public debate online, especially in digital social media, gave rise to a specific debate in Brazil during 2014: the presidential election. Taking into consideration the analyses presented above, it can be seen that the main formats of the comments were criticism and praise of the candidates. As had been shown by Brugnago and 
Chaia (2014), the behavior of readers and voters was similar to the behavior of supporters of sports teams, which also reflects the personification of the campaign, which is an intrinsic characteristic of audience democracy (MANIN, 1995) such as the Brazilian democracy.

According to Manin (1995), personification of the choice in the elections, the role of a candidate's image and the presence of the media in the appointment of leaders are consequences of transformations the representative form of government has undergone. That is why, as in the campaign, a personified journalistic coverage, aimed at each candidates' public image, has become common. This analysis has shown that this personification is also present in the debate on digital social media. This debate follows candidates' public images instead of topics, government plans or even media outlets.

The predominance of comments justified solely by users' political position, which occurred in $76.9 \%$ of the analyzed comments, further characterizes this behavior of Internet users who engage in debates. This seems to be a predominant feature of this kind of political discussion, especially because, according to Cervi (2013), justification tends to decrease as the day of the election approaches, and was even more obvious prior to the second round of voting. Taking into consideration the percentages of internal and external justifications (8.5\% and $2.3 \%$, respectively), it can be concluded that the election is a topic that is close to the heart of citizens; it is the democratic moment, which directly concerns them. Because of this, as shown by Barros and Carreiro (2015), this topic increased the need for justification in comments.

When the correlation between justifications and the format of the comments is analyzed - it is a significant, and therefore dependent, correlation - some results allow for a qualitative characterization of the debate. Justification of "position" becomes even more pronounced when the commentator praises a candidate, which strengthens their assumed role as supporter of that candidate. On the other hand, it could be seen that personal, internal justification is more frequently used to criticize a candidate, the government, the author of the post or the website itself.

Generally speaking, this analysis confirms some of the characteristics of the online behavior of Brazilian voters during the election that had been described (CERVI, 2013; BRUGNAGO; CHAIA, 2014) and indicates that journalism, even in an online environment, still performs a role of promoter of debate among its readers. This process precedes the formation of public opinion, and also, in the case of the election, precedes people's democratic participation 
through vote. It is important to note that, in spite of being in a social environment for leisure, such as Facebook, and taking into consideration the multiple actors present in the current arena of production and publishing of information, media outlets still have an important role. They are channels Internet readers can use to communicate directly with candidates, not treating them only as objects of discussion, as could be expected from the possibilities of interaction Internet channels provide.

Finally, it can be concluded that the Facebook pages of Brazilian newspapers are a space where frequent, significant, and intense political debate among citizens has developed. It is clear that the news, as a knowledge form, is still able to stimulate society to become politically active.

\section{NOTES}

1 It is common knowledge that journalistic messages are created through a process of selection and transformation of information pieces, which limits the content that finally reaches the public. Known as gatekeeping, this process indicates that the production of news is influenced by factors internal and external to the newsroom of journalistic institutions (SHOEMAKER \& VOS, 2011).

2 This is common practice in newspapers, which see this limited act as a real interaction process.

3 Gatewatching is the process in which the public contributes to the filtering of which news is read the most by selecting topics and contents that catch their attention online (BRUNS, 2006). This process is important for online communication because of the variety and complexity of the production and publishing of news and of the access to journalistic information online.

4 Data collection and categorization conducted by the Research Group for Political Communication and Public Opinion (CPOP/UFPR). The authors would like to thank all the researchers involved who performed those functions. 
REFERENCES

ALBUQUERQUE, A. Um outro 'quarto poder': imprensa e compromisso político no Brasil. Contracampo, Rio de Janeiro, n.4, p. 23-57, 2000.

BARROS, S.A.; CARREIRO, R. A discussão pública e as redes sociais online: os comentários de noticias no Facebook". Revista Fronteiras - estudos midiáticos, Rio Grande do Sul, v. 17, n.2, p. 175-185, 2015.

BAUER, M. W. Análise de Conteúdo Clássica: Uma Revisão. In: BAUER, M. W.; GASKELL, G. (Eds). Pesquisa qualitativa com texto, imagem e som: Um Manual prático. $11^{\text {a }}$ ed. Petrópolis: Vozes, p.189-217, 2013.

BRAGA, J. L. A Sociedade enfrenta sua mídia: dispositivos sociais de crítica de mídia. São Paulo: Paulus, 2006.

BRUGNAGO; CHAIA, V. A nova polarização política nas eleições de 2014: Radicalização ideológica da direita no mundo contemporâneo do Facebook. Aurora: Revista de arte, mídia e política, São Paulo, v. 7, n.21, p. 99-129, 2014.

BRUNS, A. The practice of news blogging. Uses of Blogs. New York: Peter Lang, p. 11-22, 2006.

CERVI, E. U. A Análise de Dados Categóricos em Ciência Política: Uso de testes estatísticos em tabelas de contingência com fontes secundárias de dados. Curitiba: PPGCP/UFPR, 2014a.

CERVI, E. U. Como os webleitores do 'Portal Estadão' comentaram a eleição de Dilma Rousseff em 2010: uma discussão sobre os participantes do debate público em campanhas eleitorais nos novos meios de comunicação. Explanans, México, v.2, n.1, p. 75-99, 2013.

CERVI, E. U. Eleições Casadas, Votos Solteiros e PT em Namoro Eleitoral com PSDB: Uma descrição da Tendência de Polarização das Eleições Presidenciais entre 1994 e 2014. Em Debate, Belo Horizonte, v.6, n.6, p. 25-46, 2014b.

GOMES, W.; FERNANDES, B.; REIS, L.; SILVA, T. 'Politics 2.0': a campanha on-line de Barack Obama em 2008. Revista de Sociologia e Política, Curitiba, v. 17, n. 34, p. 29-43, 2009.

JENSEN, J.L. Virtual democratic dialogue? Bringing together citizens and politicians. Information Polity, n.8, p. 29-47, 2003.

KNEWITZ, A.; JACKS, N. Reconfigurações nas práticas de leitura de notícias: como convivem o jornalismo impresso e o digital. In: SILVA, G.; KUNSCH, D.; BERGER, C.; ALBUQUERQUE, A. (Eds.). Jornalismo Contemporâneo: figuras, impasses e perspectivas. Salvador/Brasília: 
Edufba/Compos, 2011.

MANIN, B. As Metamorfoses do Governo Representativo. Revista Brasileira de Ciências Sociais, São Paulo, v.10, n.29, 1995.

MITOZO, I.B.; MASSUCHIN, M.G.; CARVALHO, F.C. de. Características do debate político-eleitoral no Facebook: Os comentários do público em posts jornalísticos nas eleições presidenciais de 2014. In: ASSOCIAÇÃO BRASILEIRA DE PESQUISADORES EM COMUNICAÇÃO E POLÍTICA (COMPOLÍTICA), 6, 2015, Rio de Janeiro. Anais do VI Encontro da COMPOLITICA, Rio de Janeiro: COMPOLÍTICA, 2015, v.1, p. 1-23. Avaible on: http://www.compolitica.org/home/wp-content/ uploads/2015/04/GT4-Mitozo-Massuchin-e-Carvalho.pdf. Access on: 30/05/2016.

PARK, R. A notícia como forma de conhecimento. In: BERGER, C. e MAROCCO, B. (Eds,). A era glacial do jornalismo: teorias sociais da imprensa. Porto Alegre: Sulina, 2008. v.2 p. 51-70, 2008.

PORTO, A. Enquadramento da Mídia e Política. In: RUBIM, A. (Ed.). Comunicação e política: conceitos e abordagens. Salvador: Edufba, 2004, p. 73-104, 2011.

ROSSETO, G.P.; CARREIRO, R.; REIS, L. Conversação política no Facebook: um estudo sobre a crise da água no Brasil. In: ASSOCIAÇÃO BRASILEIRA DE PESQUISADORES EM COMUNICAÇÃO E POLÍTICA (COMPOLÍTICA), 6, 2015, Rio de Janeiro. Anais do VI Encontro da COMPOLITICA, Rio de Janeiro: COMPOLÍTICA, 2015, v.1, p. 1-21. Avaible on: < http://www.compolitica. org/home/wp-content/uploads/2015/04/GT4-Rossetto-Carreiro-e-Reis. pdf>. Access on: 15/05/2016.

SAMPAIO, R.C.; MAIA, R.C.; MARQUES, F.P.J. Participação e deliberação na internet: um estudo de caso do Orçamento Participativo Digital de Belo Horizonte. Opinião Pública, Campinas, v.16, n.2, p. 446-477, 2010.

SHOEMAKER, P.; VOS, T. Teoria do gatekeeping: seleção e construção da notícia. Porto Alegre: Penso, 2011.

STROMER-GALLEY, J. Online interaction and why politicians avoid it. Journal of Communication, v. 50, n.4, p. 111-132, 2000.

THURMAN, N. Journalism, gatekeeping and interactivity. In: COLEMAN, S.; FREELON, D. The Handbook of Digital Politics. Cheltenham, UK: Edgward Elgar, p. 357-374, 2015.

TRIBUNAL SUPERIOR ELEITORAL. Informações sobre as eleições Eleições 2014. 2015. Avaible on: <http://www.tse.jus.br/eleicoes/ eleicoes-anteriores/eleicoes-2014/eleicoes-2014>. Access on: 02/05/2016.

TRIBUNAL SUPERIOR ELEITORAL. Partidos e candidatos têm de 
respeitar prazo de um ano para concorrer em 2014. 2013. Avaible on: <http://www.tse.jus.br/imprensa/noticias-tse/2013/Maio/ partidos-e-candidatos-tem-de-respeitar-prazo-de-um-ano-para-concorrerem-2014>. Acess on: 02/05/2016.

WEBER, M.H.; COELHO, M.P. Entre jornalismos e poderes. In: SILVA, G.; KUNSCH, D.; BERGER, C.; ALBUQUERQUE, A. (Eds). Jornalismo Contemporâneo: figuras, impasses e perspectivas. Salvador/Brasília: Edufba/Compos, 2011, p. 51-78.

Fernanda Cavassana de Carvalho. PhD candidate in Politics at the Federal University of Paraná (UFPR), and Master in Communication by the same institution. Assistant professor of Communication at the Technological University of Paraná (UTFPR). Research Group for Political Communication and Public Opinion (CPOP). E-mail: fercavassana@hotmail.com

Isabele Batista Mitozo. PhD candidate in Politics at the Federal University of Paraná (UFPR), and Master in Communication by the Federal University of Ceará (UFC). Research Group for Political Communication and Public Opinion (CPOP). E-mail: ibmitozo@gmail.com 